\title{
The Epidemiology of Leprosy in the New Hebrides
}

\author{
R. C. RATARD* AND L. L. BRAVO $\dagger$ \\ ${ }^{*}$ Chief Medical Officer, Rural Health Service, Vila, \\ New Hebrides, and †WHO Leprologist
}

\begin{abstract}
This epidemiological study of leprosy in the New Hebrides was based on a survey of the population ( $41 \%$ coverage), and the results of 20 years of case finding. The annual incidence of new cases is 0.45 per thousand. Thirteen percent are of lepromatous type. Leprosy predominates among males. The incidence of leprosy cases increases with age until the age group 30 to 44 . Leprosy is concentrated in families, in villages and in foci in which the prevalence is high. The prevalence is also very high among contacts. Most of the foci are well under control but some are still developing. In some areas there is a possibility of a small outbreak occurring. Leprosy being one of the major public health problems in the New Hebrides, a careful and selective control programme is indispensable.
\end{abstract}

\section{Introduction}

The New Hebrides is a group of islands in the Southwest Pacific 1200 miles of $f$ the eastern coast of Australia, lying between $13^{\circ}$ and $21^{\circ}$ south. There are 12 major islands (500 to 3000 sq. $\mathrm{km}$ each) and 100 tiny islets. Around the volcanic frame the coral reefs have built up low platforms, hence a mixture of mountainous areas surrounded by small coastal plains and corallian islets. The climate is tropical, hot and humid with rainy season from December to May. The indigenous people are Melanesians. Several hundreds of years ago there were migratory waves of Polynesians who settled on the coasts and islets. In these areas the indigenous population is a mixture of the original Melanesians and of Polynesians.

Although the New Hebrides was "discovered" in 1606, the first important contacts with Europeans took place during the 19th century. The epidemics that swept over the country during this period were the causes of an intense depopulation. The trend was reversed only during the 1920's. The population density is low, only 6 per sq. $\mathrm{km}$, and some islands are still very scarcely populated.

Most of the people live in the rural areas in small villages of 20 to 50 inhabitants. Their main occupation is farming. Males spend most of their time working in the gardens, taking care of the harder tasks. They also cut copra, which is the main source of wealth. Hunting, fishing and pig farming are other sources of income. Women divide their time between gardening, where they perform the less strenuous tasks, and the household. Children are often raised in the extended family, including grandparents, uncles, aunts, and cousins. From age 6 to 14 the children attend the village schools. Girls do not spend as much time in schools as boys.

The living standards and the level of hygiene are low. The average family unit has 3 buildings, including at least one kitchen and one sleeping room. In the more primitive areas there are communal houses where 10 to 20 people sleep. The most common building materials are bamboo, corrugated iron sheets and thatch. Water is available from wells, springs, or rainwater drums. The majority of the people are Christian. There is an intense circular 
migration of young adults, mostly male, going to work for several years on the plantations or in the towns.

Very little is known about leprosy in the New Hebrides in the 19th and early 20th centuries. Leprosy is commonly thought to have been introduced by European ships or labour traffic between 1820 and 1870 . The only earlier mention of leprosy was made by the French explorer Bougainville (1768) who named Aoba island the "Isle of Lepers" because of "the wounds with which these people were covered" (Dunmore, 1965). In Aoba there were many highly prevalent skin diseases that could have been mistaken for leprosy, such as ulcerative tertiary yaws, pityriasis versicolor and tinea imbricata.

In 1883 the first cases of leprosy officially notified in New Caledonia were among 4 New Hebrideans (Ragusin, 1951). However, at that time it was not widely spread. Missionaries from both Epi and Tongoa reported the absence of leprosy in their respective islands in 1894 (Cantile, 1927). In "The History of the Melanesian Mission" no mention was made of leprosy, even in Mota Lava where it became highly prevalent (Armstrong, 1900).

In 1925 Buxton and Lambert noted that "leprosy is distributed all over the New Hebrides, but it is nowhere common" (Buxton, 1927). Twelve cases were found on Tanna.

In 1932 Placidi mentioned the existence of a single case in a southeastern plantation of Santo and of a small focus on Tanna island. This focus on West Tanna vanished with the deaths of the lepers, but 10 years later in 1946 a girl from the same area developed the disease (Davies, 1951). Meanwhile in 1940 a lepromatous male working on a ship came back to his village in Port Resolution, East Tanna, From this case stemmed a new focus of leprosy. In 1962 to 1963 among 3100 people examined 39 had leprosy, i.e. a prevalence of 12.6 per thousand. Most of the cases were intrafamiliar (Mahé, 1964). On West Tanna there was only one case left.

In 1940 only one case was reported on Paama (Balzeau, 1940).

The first comprehensive survey was done by Davies from 1948 to 1951 (Davies, 1951). 21,514 persons, representing $43 \%$ of the whole population were examined (Table 1). Ninety-six leprosy cases or 4.4 per thousand examined were discovered. Some foci of leprosy were already well established on Mota Lava, West and South Santo, Malekula, Pentecost, Ambrym and East Tanna.

In the next 10 years leprosy spread in the Mota Lava focus and all over the Banks group.

TABLE 1

Davies leprosy survey of the New Hebrides 1948 to 1951

\begin{tabular}{lrccc}
\hline \multicolumn{1}{c}{ Island-area } & $\begin{array}{c}\text { Total } \\
\text { population }\end{array}$ & $\begin{array}{c}\text { Population } \\
\text { seen }\end{array}$ & $\begin{array}{c}\text { Cases } \\
\text { discovered }\end{array}$ & $\begin{array}{c}\text { Discovered cases } \\
\text { per thousand } \\
\text { examined }\end{array}$ \\
\hline Torres & 160 & 102 & 0 & 0 \\
Banks Mota Lava & 639 & 365 & 13 & 36 \\
Santo \& islets & 1955 & 1135 & 0 & 0 \\
Aoba & 4820 & 1498 & 32 & 22 \\
Maewo & 8203 & 2076 & 2 & 0 \\
Malekula & 7500 & 475 & 0 & 2.3 \\
Pentecost & 5400 & 2133 & 10 & 5.6 \\
Ambrym & 4100 & 1591 & 12 & 5.7 \\
Paama & 1400 & 1042 & 5 & 0 \\
Lopevi & 150 & 137 & 0 & 2.4 \\
Epi Lamen & 1400 & 838 & 2 & 2.9 \\
Sheperds & 2500 & 1683 & 5 & 0.9 \\
Efate \& islets & 5000 & 2121 & 2 & 3.2 \\
Tanna & 7400 & 1252 & 4 & 0 \\
Sthern islands & 1080 & 810 & 0 & 4.4 \\
Total & 48,557 & 21,514 & 96 & \\
\hline
\end{tabular}


TABLE 2

Age group distribution at diagnosis by sex and types

\begin{tabular}{|c|c|c|c|c|c|c|c|c|c|c|c|c|c|c|c|c|c|c|}
\hline & & \multicolumn{2}{|c|}{$0-14$} & \multicolumn{2}{|c|}{$15-29$} & \multicolumn{2}{|c|}{$30-44$} & \multicolumn{2}{|c|}{$45-59$} & \multicolumn{2}{|c|}{$60+$} & \multicolumn{2}{|c|}{$\begin{array}{c}\text { Total } \\
\text { known }\end{array}$} & \multicolumn{2}{|c|}{ Unknown } & \multicolumn{2}{|c|}{ Total } & \multirow[t]{2}{*}{ Total } \\
\hline & & $\mathrm{M}$ & $\mathrm{F}$ & M & $\mathrm{F}$ & M & $\mathrm{F}$ & M & $\mathrm{F}$ & M & $\mathrm{F}$ & $\mathrm{M}$ & $\mathrm{F}$ & $\mathrm{M}$ & $\mathrm{F}$ & M & $\mathrm{F}$ & \\
\hline \multirow{4}{*}{$\begin{array}{c}\text { Number of } \\
\text { new cases } \\
1957-1976\end{array}$} & I & 25 & 15 & 7 & 2 & 4 & 2 & 0 & 0 & 0 & 0 & 36 & 19 & 11 & 2 & 47 & 21 & 68 \\
\hline & $T \& B$ & 76 & 67 & 85 & 40 & 42 & 26 & 26 & 12 & 11 & 5 & 240 & 150 & 97 & 41 & 337 & 191 & 528 \\
\hline & $76 \mathrm{~L}$ & 8 & 7 & 15 & 8 & 23 & 6 & 5 & 2 & 0 & 0 & 51 & 23 & 16 & 6 & 67 & 29 & 96 \\
\hline & Total & 109 & 89 & 107 & 50 & 69 & 34 & 31 & 14 & 11 & 5 & 327 & 192 & 124 & 49 & 451 & 241 & 692 \\
\hline \multirow{4}{*}{$\begin{array}{c}\% \text { of cases } \\
\text { per age } \\
\text { group }\end{array}$} & I & \multicolumn{2}{|c|}{20} & \multicolumn{2}{|r|}{6} & \multicolumn{2}{|c|}{6} & \multicolumn{2}{|r|}{0} & \multicolumn{2}{|c|}{0} & \multicolumn{2}{|c|}{11} & \multicolumn{2}{|c|}{8} & \multicolumn{2}{|c|}{10} & \\
\hline & $T \& B$ & \multicolumn{2}{|c|}{72} & \multicolumn{2}{|c|}{79} & \multicolumn{2}{|c|}{68} & \multicolumn{2}{|c|}{84} & \multicolumn{2}{|c|}{100} & \multicolumn{2}{|c|}{75} & \multicolumn{2}{|c|}{80} & \multicolumn{2}{|c|}{77} & \\
\hline & L & \multirow{2}{*}{\multicolumn{2}{|c|}{$\begin{array}{r}8 \\
100\end{array}$}} & \multirow{2}{*}{\multicolumn{2}{|c|}{$\begin{array}{r}15 \\
100\end{array}$}} & \multirow{2}{*}{\multicolumn{2}{|c|}{$\begin{array}{r}26 \\
100\end{array}$}} & \multirow{2}{*}{\multicolumn{2}{|c|}{$\begin{array}{r}16 \\
100\end{array}$}} & \multicolumn{2}{|c|}{0} & \multirow{2}{*}{\multicolumn{2}{|c|}{$\begin{array}{r}14 \\
100\end{array}$}} & \multirow{2}{*}{\multicolumn{2}{|c|}{12}} & & & \\
\hline & Total & & & & & & & & & & & & & & & & & \\
\hline Sex ratio & $\mathrm{L}$ & & 1 & & .9 & & & & .5 & & & & & & & & & \\
\hline $\mathrm{M} / \mathrm{F}$ & Total & & .2 & & .1 & & 0 & & .2 & & & & & & & & & \\
\hline
\end{tabular}


Eight new cases had appeared in Mota Lava, bringing the total to 20 known cases (prevalence of 28.6 per thousand, incidence of new cases per year of 2.9 per thousand, Quentin, 1956).

From 1957 to 1972 the government and mission medical services carried on the case detection, treatment and follow-up of leprosy patients. A leprosarium was established in Aoba and most of the leprosy patients from the northern district were taken care of through the leprosarium. In 1973 a national leprosy control programme was established within the Rural Health Service.

\section{Material and Methods}

In order to assess the epidemiological situation of leprosy in the country, 2 methods were used:

(1) A systematic case-finding survey was undertaken from October 1973 to 1976. The objectives of the survey were to establish leprosy prevalence rates in some islands, to complete the date on the leprosy patterns in known foci of leprosy and to assess the situation in unknown areas. The survey was not based on a random sampling of the population, but rather on the following criteria: (a) examination of the entire population in the known foci of leprosy; (b) examination of as many leprosy contacts as possible; (c) examination of the entire population in areas where the situation was unknown; (d) examination of a small sample of population in areas where it was already established that leprosy was not prevalent.

(2) The establishment of a central register of all cases found. These cases were found during systematic case finding surveys carried out from 1957 to 1976. It is estimated that for this period of 20 years that at least $90 \%$ of the leprosy cases were registered. Because of this the epidemiological situation described in this paper can be considered as accurate.

The ages of patients mentioned throughout this work are the ages given at the time of diagnosis. For some patients ages were not recorded in years but as either children, adolescent, adult or elderly. These ages were recorded as unknown in Table 2, but since age group divisions of 15 years were used it seemed reasonable to include them in their age group to estimate the incidence of new cases.

\section{Results}

\section{NUMBER OF LEPROSY CASES}

In this period of 20 years, 1957 to 1976 , a total of 692 cases were found. The average annual incidence for the period calculated with the population of 1967 was 0.45 per thousand per year. It is estimated that at least $80 \%$ to $90 \%$ of the new cases were registered.

During the 1973 to 1976 survey 40,789 people were examined ( $41 \%$ of the total population) and 119 new cases were found (2.9 new cases per thousand population examined). In December 1976 there were 253 leprosy patients considered as active and receiving treatment. This number of patients depends on the criteria used to release or keep patients on control.

\section{TYPES OF LEPROSY}

The distribution of the leprosy cases according to type is presented in Tables 2 and 3 . The average incidence of new cases per thousand per year is also presented. Thirteen per cent were

TABLE 3

Distribution of leprosy according to types

\begin{tabular}{|c|c|c|c|c|c|}
\hline & 1 & $\mathrm{~T}$ & $\mathrm{~B}$ & $\mathrm{~L}$ & Total \\
\hline Number of cases & 68 & 322 & 206 & 96 & 692 \\
\hline Percentage & 10 & 47 & 30 & 13 & 100 \\
\hline \multicolumn{6}{|l|}{ Incidence of } \\
\hline $\begin{array}{l}\text { new cases per yr } \\
\text { per } 1000\end{array}$ & 0.04 & 0.21 & 0.13 & 0.07 & 0.45 \\
\hline
\end{tabular}


lepromatous, $10 \%$ indeterminate, and $77 \%$ borderline and tuberculoid. The criteria of distinction between borderline and tuberculoid varies with successive surveys. Due to this the distinction between these 2 types is not very meaningful.

The proportion of lepromatous cases is low as in the African countries. It is also low in comparison with other countries of the South Pacific. The low proportion of indeterminates indicates that diagnosis is made late when the disease has already developed into a more polar type. The average incidence of the lepromatous type is 0.07 per thousand per year. With such a low incidence a wide proportion of the population is not exposed to infectious cases.

\section{LEPROSY AND SEX}

Leprosy is more common in males than in females as shown by the incidences of new cases per year per thousand. There is an incidence of 0.56 among males and 0.34 among females using as a denominator the population in 1967. The male/female ratio is 1.9:1. The distribution of leprosy types is similar among males and females and the ratios are 2.2:1 for indeterminate, 1.8:1 for tuberculosis and borderline, and 1.9:1 for lepromatous.

TABLE 4

Distribution of leprosy according to sex

\begin{tabular}{lllll}
\hline & & M & \multicolumn{1}{c}{ F } & Total \\
\hline Number of cases & Total & 451 & 241 & 692 \\
& I & 47 & 21 & 68 \\
& T \& B & 337 & 191 & 528 \\
Incidence of & L & 67 & 29 & 96 \\
new cases per yr per & T \& B & 0.42 & 0.27 & 0.34 \\
thousand & L & 0.08 & 0.04 & 0.07 \\
& Total & 0.56 & 0.34 & 0.45 \\
\hline
\end{tabular}

It has been commonly observed that the ratio between male and female lepromatous is $2: 1$ but in non-lepromatous leprosy, the ratio is not as high. This predominance of male lepromatous is thought to be due to a higher susceptibility of males.

\section{LEPROSY AND AGE}

The data on distribution of leprosy by age groups of 15 years are presented in Tables 1 and 5. The incidence was calculated using as a denominator the population in 1967.

The incidence of new cases increases with age up to a peak at age 30 to 44 and then slowly decreases (Fig. 1).

TABLE 5

Distribution of leprosy according to age*

\begin{tabular}{lrrrrrrr}
\hline & & $0-14$ & $15-29$ & $30-44$ & $45-59$ & $60+$ & Total \\
\hline $\begin{array}{l}\text { Est. number } \\
\quad \text { of cases }\end{array}$ & & 264 & 209 & 137 & 61 & 21 & 692 \\
Incidence & $\mathrm{I}$ & 0.07 & 0.03 & 0.03 & 0.00 & 0.00 & 0.04 \\
$\quad$ of new cases & $\mathrm{T} \& \mathrm{~B}$ & 0.28 & 0.42 & 0.38 & 0.37 & 0.27 & 0.34 \\
$\quad$ per thousand & $\mathrm{L}$ & 0.03 & 0.07 & 0.16 & 0.13 & 0.00 & 0.07 \\
& Total & 0.38 & 0.52 & 0.57 & 0.50 & 0.27 & 0.45 \\
\hline
\end{tabular}

* In this table an estimation was made about the age of the unknown to get fid of this category. 

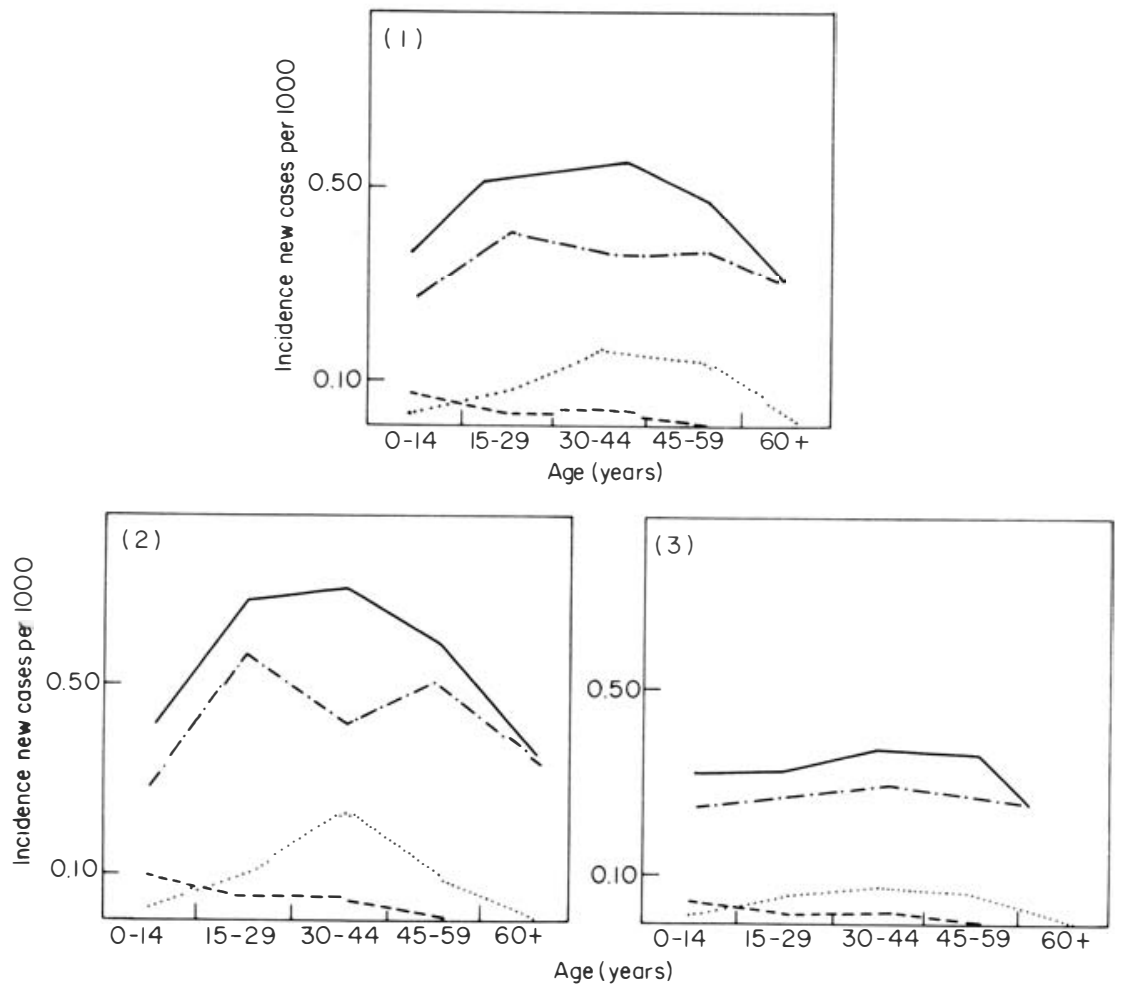

Fig. 1. Distribution of leprosy according to age. (—_ ) total; (.-. ) B \& T; (. . . . .) L; $(---)$ I.

Fig. 2. Distribution of leprosy according to age among males. (—_ (. . .....) L; $(----) \mathrm{I}$.

Fig. 3. Distribution of leprosy according to age among females. (—-) total; (.-.-) B \& $\mathrm{T}$; (......) $\mathrm{L} ;(----) \mathrm{I}$.

The sex distribution is not the same in all groups. The ratio of males to females is around $1: 1$ in the age group 0 to 14 , then around $2: 1$ in the older age groups. This applies for all types of leprosy. In most surveys lepromatous leprosy was shown to have a male predominance only in persons over 14 years of age (Bechelli and Martinez Dominguez, 1963).

\section{GEOGRAPHICAL DISTRIBUTION OF LEPROSY IN THE NEW HEBRIDES}

Leprosy is distributed in foci with very high incidence and prevalence in some islands or areas and very low in others (Tables 6 and 7). In some islands, such as Mota Lava, the incidence may be as high as 3.25 per thousand per year. An incidence of new cases above 1 per thousand per year may be considered as high incidence in the New Hebrides.

There is a good correlation between the number of new cases per year and the number of active cases, with the number of active cases being about 5 times the number of new cases. In areas with a high proportion of lepromatous, the number of active cases tends to be higher since lepromatous patients are kept on treatment for years.

There is also a good correlation between annual incidence of lepromatous cases and annual incidence of all leprosy cases. In Fig. 4 each island or area was plotted according to their 
TABLE 6

Geographical distribution of leprosy. New cases 1957 to 1976

\begin{tabular}{|c|c|c|c|c|c|c|c|c|}
\hline \multirow[b]{2}{*}{ Island } & \multirow[b]{2}{*}{ Area } & \multirow{2}{*}{$\begin{array}{c}\text { Population } \\
1967\end{array}$} & \multicolumn{3}{|c|}{ New cases } & \multirow[b]{2}{*}{ Total } & \multicolumn{2}{|c|}{$\begin{array}{c}\text { Incidence } \\
\text { New cases } \\
\text { per } 1000 \text { per year }\end{array}$} \\
\hline & & & I & $B+T$ & $\mathrm{~L}$ & & $\mathrm{~L}$ & Total \\
\hline Torres & Mota Lava & 200 & 0 & 0 & 1 & 1 & 0.25 & 0.25 \\
\hline \multirow[t]{4}{*}{ Banks } & Mota Lava & 816 & 7 & 30 & 16 & 53 & 0.98 & 3.25 \\
\hline & Vanua Lava & 747 & 1 & 12 & 4 & 17 & 0.27 & 1.14 \\
\hline & Mota & 269 & 1 & 11 & 2 & 14 & 0.37 & 2.60 \\
\hline & Other & 1,449 & 1 & 13 & 0 & 14 & 0 & 0.48 \\
\hline Santo & N.E. \& C & 4,932 & 4 & 44 & 8 & 56 & 0.08 & 0.56 \\
\hline \multirow[t]{3}{*}{ Rural } & South \& Islets & 2,504 & 12 & 94 & 15 & 121 & 0.26 & 2.37 \\
\hline & West & 917 & 1 & 29 & 2 & 32 & 0.10 & 1.74 \\
\hline & Malo & 1,594 & 0 & 3 & 1 & 4 & 0.03 & 0.12 \\
\hline Aoba & & 5,971 & 4 & 28 & 7 & 39 & 0.05 & 0.28 \\
\hline Maewo & & 1,196 & 0 & 5 & 0 & 5 & 0 & 0.21 \\
\hline Malekula & & 11,182 & 1 & 4 & 1 & 6 & 0 & 0.03 \\
\hline Pentecost & & 6,801 & 15 & 67 & 6 & 88 & 0.04 & 0.65 \\
\hline Ambrym & & 4,246 & 11 & 61 & 6 & 78 & 0.07 & 0.91 \\
\hline Paama & & 1,947 & 3 & 49 & 9 & 61 & 0.23 & 1.67 \\
\hline Epi Lamen & & 2,032 & 5 & 44 & 3 & 52 & 0.06 & 1.28 \\
\hline Sheperds & & 3,594 & 0 & 5 & 1 & 6 & 0.01 & 0.08 \\
\hline Efate & Rural & 6,699 & 0 & 4 & 4 & 8 & 0.03 & 0.06 \\
\hline Tanna & & 10,476 & 2 & 21 & 6 & 29 & 0.03 & 0.14 \\
\hline Aniwa & & 227 & 0 & 4 & 3 & 7 & 0.66 & 1.54 \\
\hline South islets & & 1,110 & 0 & 0 & 1 & 1 & 0.04 & 0.04 \\
\hline Towns & & 7,673 & 0 & 0 & 0 & 0 & 0 & 0 \\
\hline Total & & 76,582 & 68 & 528 & 96 & 692 & 0.07 & 0.45 \\
\hline
\end{tabular}

TABLE 7

Contact tracing

\begin{tabular}{ccccc}
\hline & & $\begin{array}{r}\text { Contacts } \\
\text { examined }\end{array}$ & $\begin{array}{l}\text { New } \\
\text { cases }\end{array}$ & $\begin{array}{c}\text { New cases } \\
\text { per thousand }\end{array}$ \\
\hline Index & I & 62 & 0 & 0 \\
case & T and B & 555 & 5 & 9.0 \\
& L & 147 & 17 & 115.6 \\
& Total & 764 & 22 & 28.8 \\
\hline
\end{tabular}

incidence of lepromatous cases and total leprosy cases. One would expect such a situation where the lepromatous prevalence is low (Newell, 1966).

Leprosy is not evenly distributed in these areas of endemicity. The distribution of leprosy at village level is as follows:

\begin{tabular}{crc}
\hline Villages with no cases at all & 1753 & $87 \%$ \\
One case only & 158 & $8 \%$ \\
2 to 5 cases & 78 & $4 \%$ \\
5 to 10 cases & 20 & $1 \%$ \\
More than 10 cases & 11 & $0.5 \%$ \\
Total number of villages & 2000 & \\
\hline
\end{tabular}




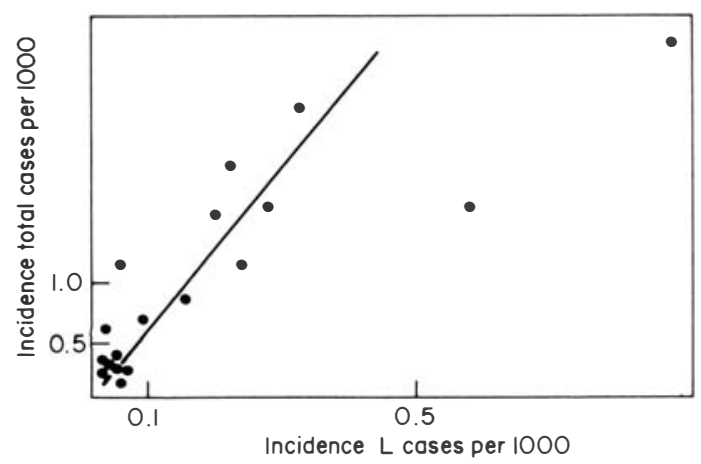

Fig. 4. Correlation between lepromatous and total cases.

The highest annual incidence may be quite high in some villages. It ranges from 5 per thousand to 20 per thousand in these 10 most endemic villages. This is 10 to 40 times more than the national average. This concentration of cases in villages has been observed in most endemic areas.

\section{CONTACT TRACING, INTRAFAMILIAR CASES}

For 405 cases data was available on the presence of other cases in the family. "Family" is considered to include father, mother, children, grandparents, and single aunts or uncles. There are about 10 persons in such a family and about 8 to 10,000 families in the country.

\begin{tabular}{|c|c|}
\hline $\begin{array}{l}\text { Families with a single case } \\
\qquad \begin{array}{l}2 \text { cases } \\
3 \text { cases } \\
4 \text { cases } \\
5 \text { or more cases }\end{array}\end{array}$ & $\begin{array}{r}110 \\
78 \\
22 \\
11 \\
7\end{array}$ \\
\hline Total & 228 \\
\hline
\end{tabular}

Contact surveys prove to be the most useful way to find new cases as shown in Table 7 .

The rate for new cases discovered per examiisd (thousand) was 2.9 in the whole population, 9.0 among contacts of tuberculoid and borderline cases or 3 times more, and 116 among contacts of lepromatous cases or 40 times more. Similar observations in other countries showed twice the annual attack rate of the general community among contacts of tuberculoid cases and 8 times among contacts of lepromatous cases (Doull, 1961).

\section{CLINICAL AND BACTERIOLOGICAL CONDITION OF PATIENTS}

The data are presented in Table 8 . The classical clinical patterns of leprosy types hold true for the New Hebrides. The percentage of disabled is high in comparison with other countries of the South Pacific [39\% in the New Hebrides, 22\% in French Polynesia, 17\% in Tonga (Bechelli and Martinez Dominguez, 1972)]. The percentage of positive cases is $38 \%$ of the total cases, $100 \%$ of the lepromatous, $20 \%$ of the tuberculoid and borderline, and $4 \%$ of the indeterminate. The percentage of bacteriological positive cases for total cases is biased because more positive cases were examined.

The average duration of symptoms before diagnosis was 3 years 5 months for lepromatous, 2 years 7 months for tuberculoid and borderline. and 1 year 10 months for indeterminate cases. 


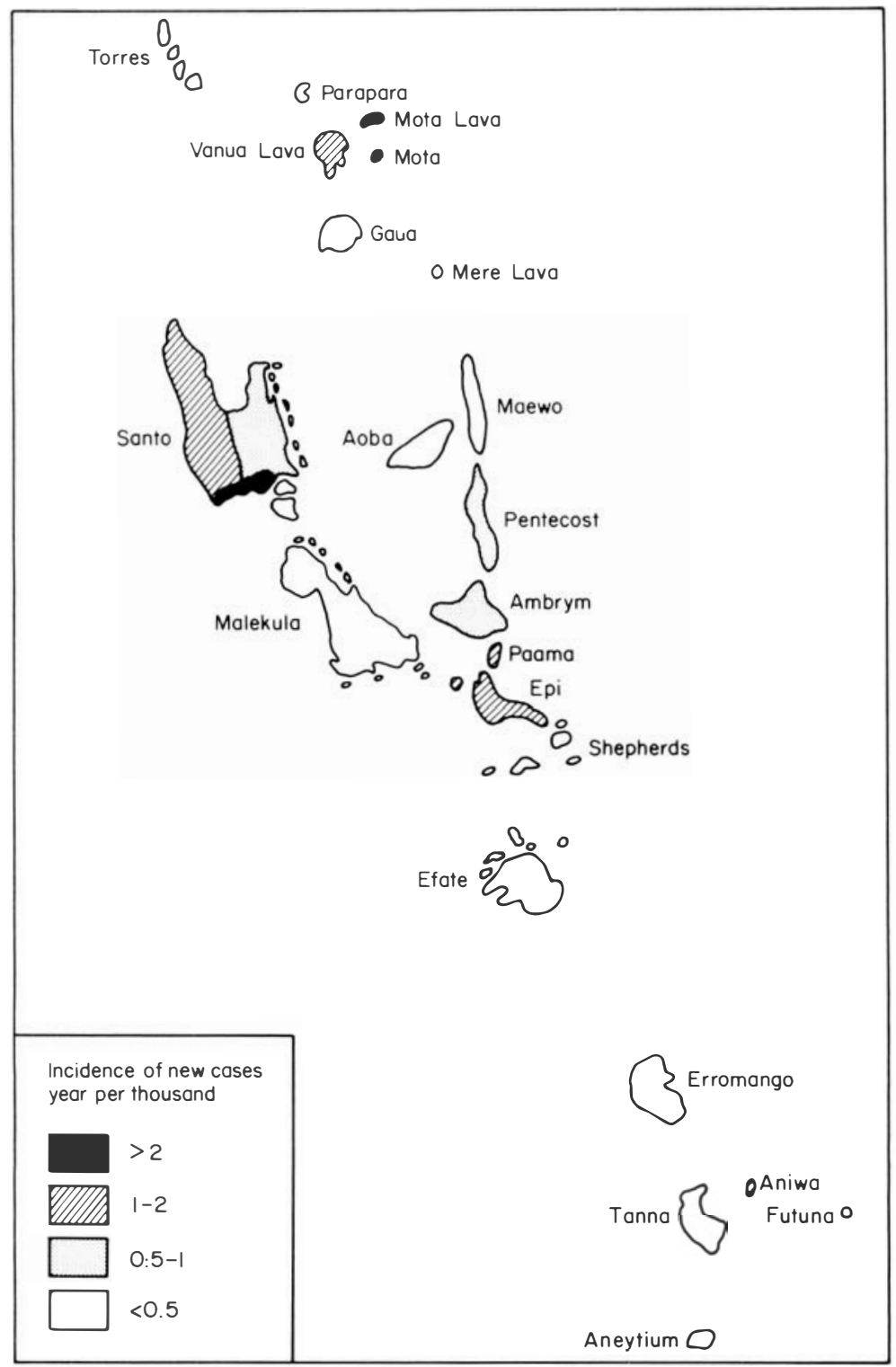

Map of leprosy in the New Hebrides. 
TABLE 8

Clinical and bacteriological status of patients at diagnosis

\begin{tabular}{|c|c|c|c|c|c|c|c|c|c|c|c|c|c|c|c|}
\hline & \multirow[b]{2}{*}{$\begin{array}{c}\text { Total } \\
\text { number } \\
\text { of cases }\end{array}$} & \multicolumn{9}{|c|}{ Clinical condition $(\%)$} & \multicolumn{3}{|c|}{ Disability } & \multicolumn{2}{|c|}{ Bacteriology } \\
\hline & & $\begin{array}{c}\text { Cases } \\
\text { studied }\end{array}$ & Macules & Inf iltrate & Nodules & Anaesthesia & Pain & Paralysis & $\begin{array}{c}\text { Enlarged } \\
\text { nerve }\end{array}$ & Ulcers & $\begin{array}{c}\text { Cases } \\
\text { studied }\end{array}$ & $\%$ dis. & D.I. & Cases* & $\begin{array}{c}\text { Positive } \\
\%\end{array}$ \\
\hline I & 68 & 30 & 100 & 0 & 0 & 7 & 0 & 0 & 0 & 0 & 31 & 0 & - & 24 & 4 \\
\hline $\mathrm{T}+\mathrm{B}$ & 528 & 285 & 44 & 39 & 0 & 40 & 2 & 18 & 44 & 6 & 252 & 38 & 0.8 & 249 & 20 \\
\hline $\mathrm{L}$ & 96 & 42 & 43 & 48 & 14 & 64 & 5 & 21 & 48 & 17 & 46 & 67 & 1.2 & 83 & 100 \\
\hline Total & 692 & 357 & 49 & 36 & 2 & 68 & 2 & 19 & 46 & 7 & 329 & 39 & 0.8 & 356 & 38 \\
\hline
\end{tabular}

* This distribution is biased, more L cases were studied. 
Death rates cannot be presented since deaths of patients released from control are not recorded. However, the number of deaths among lepromatous seems to be 2 times greater than among other leprosy patients.

\section{Discussion}

Leprosy may be considered as a major public health problem in the New Hebrides. The number of active cases is 2.5 per thousand population, the number of lepromatous is 0.7 per thousand population. The incidence of new cases is 0.45 per thousand per year. These rates are low in comparison with other countries of the South Pacific. However, active measures of control have to be continued since the situation is not at all stabilized.

Due to a lack of previous data it is difficult to ascertain the evolution of the disease. Leprosy was believed to have been introduced about a 100 years ago in a few places. Foci of the disease developed slowly and the spread to other islands was hesitant and uneven. This illustrates the very slow progression of the disease due to a long incubation period, the scarcity of highly contagious cases, and the widespread resistance among the population. Leprosy is increasing in some islands. The existing pockets of lepromatous cases of Mota Lava and the northern half of Santo have maintained an active source of contagion. New cases are to be expected among the younger age groups.

In some islands of the southern half of the group, Epi, Paama and Eniwa, leprosy foci became established only within the last 20 years. A high number of new cases might be expected there in all age groups. Even in islands with no leprosy, such as Futuna and Anatom, or where leprosy was recently imported, as in Erromango, the possiblity of leprosy epidemics cannot be ruled out. In Pentecost, Malekula and Ambrym, the central islands, known foci are on the decline and have lost their potential of contagiousness. The present control programme must be flexible enough to adapt the preventive measures according to each area.

\begin{tabular}{|c|c|c|}
\hline & Area & $\begin{array}{l}\text { Control measure to be } \\
\text { specially recommended }\end{array}$ \\
\hline & Any focus & $\begin{array}{l}\text { Contact survey and follow up of } \\
\text { patients }\end{array}$ \\
\hline (2) & $\begin{array}{l}\text { Disappearing focus } \\
\text { (Pentecost, Ambrym, Malekula) }\end{array}$ & No supplementary measure \\
\hline (3) & $\begin{array}{l}\text { Old focus, still active } \\
\text { (Mota Lava, West Santo) }\end{array}$ & $\begin{array}{l}\text { Contact survey } \\
\text { Case finding among children }\end{array}$ \\
\hline (4) & $\begin{array}{l}\text { Recent focus, very active } \\
\text { (Paama, Epi) }\end{array}$ & $\begin{array}{l}\text { Contact survey } \\
\text { Case finding among all age groups }\end{array}$ \\
\hline (5) & $\begin{array}{l}\text { Recent focus, few imported cases } \\
\text { (Erromango) }\end{array}$ & Contact survey \\
\hline (6) & Non-endemic area & No supplementary measure \\
\hline
\end{tabular}

\section{Acknowledgement}

Thanks are due to the World Health Organization for permission to publish this paper.

\section{References}

Armstrong, E. S. (1900). The History of the Melanesian Mission. Ibister, London.

Balzeau, R. (1940). Rapport du Service de Santé, Vila.

Bechelli, L. M. and Martinez-Dominquez, V. (1963). WHO epidemiologic random sample surveys of leprosy in Northern Nigeria (Katsina), Cameroon and Thailand (Khon Kaen). Int. J. Lep. 34. 223.

Bechelli, L. M. and Martinez-Dominguez, V. (1966). The leprosy problem in the world. Bull. Wld Hlth Org. 34, 811. 
Bechelli, L. M. and Martinez-Dominguez, V. (1972). Further information on the leprosy problem in the world. Bull. Wld Hlth Org. 46, 523.

Bechelli, L. M. et al. (1973). Some epidemiological data on leprosy collected in a mass survey in Burma. Bull. Wld. Hlth Org. 48, 335.

Buxton, P. A. (1926). The depopulation of the New Hebrides and other parts of Melanesia. Trans. R. Soc. trop. Med. Hyg. 19, 420.

Cantile, T. (1927). Prize Essays on Leprosy. The New Sydenham Society, London.

Davies, E. J. (1951). Leprosy Survey in the New Hebrides. Lepers Trust Board, Christchurch.

Doull, J. A. (1961). Present status and problems. In Transactions of the Symposium on Research in Leprosy, Baltimore, Md., May 1961. Leonard Wood Memorial, Washington D.C.

Dun more, J. (1965). French Explorers in the Pacific. Clarendon press, Oxford.

Lambert, S. M. (1928). Medical Conditions in the South Pacific. Med. J. Aust. 2, 362.

Mahé, M. (1964). Historique de la lèpre à Port-Résolution, Tanna. Rapport Annuel de l' Hôpital Français de Tanna, Vila.

Newell, K. W. (1966). An epidemiologist's view of leprosy. Bull. Wld Hlth Org. 34, 827.

Placidi, T. (1932). L a Médecine et l' Hygiène a ux Nouvelles Hébrides. Rev. Med. Hyg. Trop. 24, 183.

Quentin, H. (1956). Observations sur les lépreux recensés aux Banks. Rapport de Tournée, Vila. Ragusin, E. (1951). La lèpre en Nouvelle Calédonie et Dépendances. Int. J. Lep. 19, 413. 